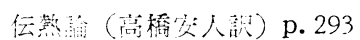

(13) 原，日本活化学会誌投稿杉

(14) D.F.Othmer, Anal, Chem. 20, 763 (1948)

(15) D. T. C. Gillespie, I. E. C., Anal. Ed., 18, 575 (1946)

(16) C.A.Jones, E.M., and A.P.Colburn, I.E.C., 35, 666 (1943)

(17) D.F.Othmer, E.H.TenEyck and S.Tolin, I.E.C., 43, 1607 (1951)

(18) E. H. TenEyck and D.F. Othmer, Petroleum Refinery, 32, No.9, 229 ; No. 10, 151 (1953)
(19) J.H.Perry, Chemical Engineer's Handbook, p. 165 (1950)

(20) V. A. Kalichevsky \& K. A. Kobe, Petroleum Refining with Chernicals, p. 51

(21) Kirk-Othmer, Encyclopedia of Chemical Technology, 14, p. 611

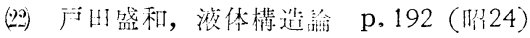

(28) L.H.Thomas, J.Chem. Soc., 3411 (1949)

(24) L.Riedel, Chem. Ind. Technik, 24, 6 (1952)

(25) Bosh, 工桨伀熱裙（高橋安人訳）

(26) 原, 活化学, 投稿中

\title{
黒心可鍛鋳鉄の酸による発生期水素の拡散について
}

\section{美馬善草艾 \\ Studies on Action of Acid Solution upon Black Heart Malleable Cast Iron and on Diffusion of Hydrogen Through the Metal.}

Yoshifumi MIMA*

An apparatus has been devised so as to be able to measure quantitatively the rate of hydrogen diffusion through black heart malleable cast iron sheet ( $3 \mathrm{~mm}$ thickness).

Operation of the apparatus was as follows:

A sheet of the metal was clamped between a stout glass cylinder with a polished flange at the bottom and a strong glass saucer with a substantial flange, the upper surface of which was. grounded.

The base of the saucer was connected with a manometer which served as gastight sealing. The metal sheet (specimen) was exposed to the attack of acid on one side. Through the metal sheet the diffused hydrogen was absorbed in the vacuum of the saucer, and the accumulated hydrogen was measured by the manometer.

The area exposed to acid of the specimen of $9 \mathrm{~cm}$ in diameter was $36.30 \mathrm{~cm}^{2}$, and its chemical compositions was C $2.81 \%$, Si $0.95 \%$, Mn $0.38 \%$, and S 0.08 .

The acids used were $1 \mathrm{~N}$ solution of $\mathrm{HCl}$ and $1 \mathrm{~N} \sim 3 \mathrm{~N}$ of $\mathrm{H}_{2} \mathrm{SO}_{4}$, and the temperature was $10^{\circ} \sim$ $30^{\circ} \mathrm{C}$.

The result is as follows:

The time required for saturating the specimens of metal with diffused hydrogen varies depending on the structure and temper carbons.

(1) It is 1,620 10,080 min. for the specimens of lamellar pearlite containing small temper carbons of up to $0.025 \mathrm{~mm}$ in diameter.

(2) It is $420 \sim 1,080 \mathrm{~min}$. for the spcimens of bull's eye structure and containing the same small temper carbons as the above.

$\dagger$ 「黑心可鍛鋳鉄の溶融亚鉛メッキに関する研究」（第 1 報）

* 大阪府立大学工.業短期大学部（浸屋川市泰） Osaka Prefectural Univ. Junior College of Eng. 
(3) It is $70 \sim 300 \mathrm{~min}$. for the specimens of ferrite structure containing small temper carbons of $0.025 \mathrm{~mm}$ and up to $0.05 \mathrm{~mm}$ in diameter.

(4) It is 1 45 min. for the specimens of ferrite structure containing large temper carbons of $0.075 \mathrm{~mm}$ and $0.10 \mathrm{~mm}$.

\section{1. 緒言}

黒心可鍛鋳鉄の溶融业鉊メッキの前処理として行なら 酸洗は黒心可鍛鋳鉄の機械的強度，业鉛メッキの組織， 付着量, 表面性などにいちじるしい影響を与える。これ らの影響は, 酸洗する場合, 発生期水素が素地中に拡散 吸蔵されることに基づく。酸洗の影響を検討するにはま ずこの基礎的現象を究明する必要がある。

従来鋳鋼の酸洗に対しては C.A.Edwards ${ }^{1)}$ その他多 くの学者によって詳細な研究が行なわれたが，黑心可鍛 鋳鉄に対してはこの種の基礎的な研究報文に接しなかっ た。

著者は本研究において，黒心可鍛鋳鉄製円板の片面を 酸処理し発生期水素を拡散せしめ, 他面からこれを真空 中に放出せしめる方法によって, 発生期水素の抎散透過 の現象について検討した。

\section{2. 実 験 方 法}

\section{2-1 試 料}

黒心可鍛鋳鉄円板試料はこの実験のために旭可鍛株式 会社に依頼して製作されたもので，白銑時の化学組成は ${ }^{+} \mathrm{C} 2.81 \%$, Si $0.95 \%, \mathrm{Mn} 0.38 \%, \mathrm{~S} 0.08 \%$ ，第 2 段 黒鉛化を施したフェライト型黑心们鍛鋳鉄であった。こ れら一群の試料の大キサは直径 $9 \mathrm{~cm}$, 厚サ $5 \mathrm{~mm}$ の円 板状のもので, 実験に当ってこれらの表面性および厚サ 淀にするため两面から機械切削により $1 \mathrm{~mm}$ むて削

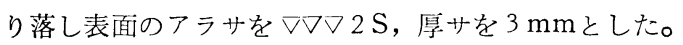
一部の試料は片面を黒皮のまま残し他面を機械仕上して 厚サを $3 \mathrm{~mm}$ とした。

これらの陚料はすべて肉腿および 7 倍の应大鏡を朋い て表面を検查し，キズまたは巣のあるものを除いた。

\section{2-2 実験装置}

実験装置の断面図を第 1 図に示した。

$\mathrm{A}$ (酸槽) は $5 \mathrm{~mm}$ 厚のガラス製问筒 (内径 $65 \mathrm{~mm}$ ) で，底部には厚サ $15 \mathrm{~mm}$, 幅 $33 \mathrm{~mm}$ のフランジが突き 出している。フランジの試料と接触する部分は砳摩して 平面とした。 $\mathrm{B}$ (ガスだめ) は肉厚ガラス製のロート状 のもので, 上部 (内径 $65 \mathrm{~mm}$ ) にはフランジ（厚サ 15 $\mathrm{mm}$, 愊 $33 \mathrm{~mm}$ ) が突さ出ている。このフランジの上面 はAのフランジの下面と相詨するようになっていて, 試 料を取付けたとき気密になるように研摩して平面とし た。Bの底部（D）にマノメーター（M）を取付けるた
めスリ合せを施し，真空用グリースを用いて気密にし た。マノメーターは肉厚の内径 $2 \mathrm{~mm}$ のガラス管で作 り，中央上部にコック（I）を取付けて，この上部々真 空ポンプが連結されるよ5になっている。マノメーター は水銀柱の指差 $205 \mathrm{~mm}$ まで測定でさる。ガスだめ ( B) およびマノメーターのガスだめの部分の総容積は $64 \mathrm{cc}$ であり，水銀柱の指差 $1 \mathrm{~mm}$ のさこの中には標準状況 で $0.084 \mathrm{cc}$ のガスが存在することになる。試料と酸と の接する面積, および真空中の放出面積はともに 33.18 $\mathrm{cm}^{2}$ であるから, 試料 $1 \mathrm{~cm}^{2}$ 当たりの ガス放出量は $0.0025 \mathrm{cc}$ に相当することになる。

肉眼および拡大鏡で検査して選出したキズまたは巣の ない試料をェーテルを用いて油を十分除いた。 Bのフラ ンジのスリ合わせ面に真空グリースを塗布して試料 (C) を密着させ,さらに試料の外周とフランジとの間は真空 用シールドワックス（大阪科学資材製）を用いて完全に 気密とした。AおよびBのフランジで試料をはさんだと きに生ずる間ゲキ部は試料と同一の厚サの金属製ワッシ ヤー（F）で埋めて，クランプ $(\mathrm{H})$ で締めつけたとき これらのフランジが壊れないようにした。試料と Aのフ ランジの間には肉厚のゴム製ワッシャー（G）を置いて 酸液が漏れないよ5にした。実験中の温度調節のため空 気恒温槽を用いた。この大キサは高さ $810 \mathrm{~mm}$, 横 1135 $\mathrm{mm}$, 奥行き $710 \mathrm{~mm}$, 壁の厚サ $70 \mathrm{~mm}$, 断熱のためモミ ガラを封入した。この空気恒温槽の中に 4 組の装置が入 れられ，電熱で自動制御方式で恒温が保たれるよ5にし た。槽の底部の 2 力所に小型のプロペラーを取付けて空 気カクハンを行ない槽内の温度分布を均一になるように
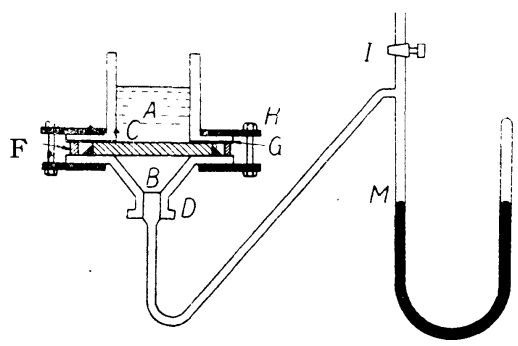
$\mathrm{A}$ : 酸 槽
$\mathrm{G}:$ ゴム製ワッシャー
B : ガスだめ
$\mathrm{H}$ : クランプ ( 4 組)
$\mathrm{C}:$ 敦 料
$\mathrm{D}$ : マノメーター取付部
$\mathrm{F} ：$ 金属製ワッシャー
$\mathrm{M}:$ : メーター
I : コック
（真空装置に接続する）

第1図装置の断面困 
した。温度調節は $\pm 0.1^{\circ} \mathrm{C}$ 程度であった。マノメーター の水銀柱の読みは槽の前面に取付けた二重ガラスの屝 $(820 \mathrm{~mm} \times 520 \mathrm{~mm})$ を透して, 槽の内部に取付けた䖝 光燈により容易に読みとれるようにした。

\section{2-3 実験方法}

キズおよび巣のない試料について酸処理前さらに真空 による選別を行なった。試料を前記 $(2-2)$ のように して取付けた後, 真空装置によって $10^{-3} \mathrm{~mm}$ (ガイスラ 一管による）程度に真空にして $1 \mathrm{hr}$ 放置して,このうち $10^{-1} \mathrm{~mm}$ 程度に真空が保たれるものを選び出し, 酸処理 実験に供した。これら真空試験に合格した試料を装置に 取付けて, 蒸留水 $100 \mathrm{cc}$ を Aに入れて $24 \mathrm{hr}$ 放置し水銀 柱の指差が $2 \mathrm{~mm}$ (以下 $2 \mathrm{mmHg}$ と略称する) 以下のと きは, 水を取り出し所要の温度とした $100 \mathrm{cc}$ の酸液と入 れ替えて水素ガスの拡散透過の実験を行なった。

\section{3. 実験結果および考察}

\section{3一1 水素ガスが透過するまでの時間（min）}

試料の上面と酸とが反応して生ずる発生期水素が試料 中に拡散して下面から真空中に放出されるまでの時間

(min) を测定した（以下この値を $\alpha$ と称する）。この 奏験装置では水銀柱の指差を正確に読みとり得る最小価 は $0.5 \mathrm{mmHg}$ であった。したがって $\alpha$ の值は $0.5 \mathrm{~mm}$ $\mathrm{Hg}$ を示すまでの時間 $(\mathrm{min})$ とした。

塭酸の渋度 $1 \mathrm{~N}, 2 \mathrm{~N}, 3 \mathrm{~N}$, 温度 $10^{\circ} \mathrm{C}$, 硫酸の濃度 $1 \mathrm{~N}, 2 \mathrm{~N}, 3 \mathrm{~N}$, 温度 $10^{\circ} \mathrm{C}, 20^{\circ} \mathrm{C}, 30^{\circ} \mathrm{C}$ に区分して実 験した結果を第 1 表に示した。

$\boldsymbol{\alpha}$ の值は試料中に水素が飽和されるまでの時間であっ て,この值が素材の水素ゼイ性またはメッキ時に水素ガ スの放出によるメッキ組織に及ぼす影響などに対して最
も重要な值であると思われる。

同一条件で製作されたこれら一群の黑心可鍛鋳鉄の試 料に対して酸の種類, 酸の濃度, 温度によって $\alpha$ の值に ある一定の影響を示すものと想したが，第1表のよう に全く予想に反した結果となった。このことはこれらの 影響より遥かにいちじるしく影響する因子が存在するも のであることがわかる。

しかしながら第 1 表において $10^{\circ} \mathrm{C}$ における塩酸と硫酸 との值はかなりの開きを示し，塩酸は水素ガスを透過さ せ難いことがうかがわれる。また片面黑皮で残したもの と, 両面とも切削したものとを比較して第 1 表からはな んらの相違もうかがうことはできない。

これより考察を進めるに当って一応酸の濃度および温 度の影響は本奏験の範㽗内では無視できるものと仮定し て，他の重要な因子を探究することにした。

\section{3-2 $\alpha$ 值と試料の組織との関係}

試料が酸に接してからガスが透過㸡出されるまでの時 間（ $\alpha \mathrm{min} ）$ に最も影響を与える因子を探究するため， まず試料の組織について検討した。

$3-2-1$ パーライト組織

$\alpha$ の最大值 $10080 \mathrm{~min}$ を示した試料 No. 1 の組織は， 多量の層状パーライトおよび球状セメンタイトを残して いた。これを写真 1 に示した。析出した黒鉛粒は小さく これらの直径はほとんど $0.025 \mathrm{~mm}$ のものおよ゙それ以 下であった。この試料は $1 \mathrm{~N} \mathrm{HCl} 10^{\circ} \mathrm{C}$ の処理で7 日間 全く水素ガスの透過が見られなかったため実験を打切っ

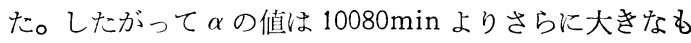
のである。また試料 No.30は $1 \mathrm{~N} \mathrm{HNO}_{3} \quad 10^{\circ} \mathrm{C}$ の処理で No. 1 試料と同様 7 日間全〈水素ガスの透過を見なかっ た。この試料の組織もまた多量の層状パーライトを残し

第1表 水素ガス唀過放出開始までの時間 (mim)

( $\alpha$ 值)

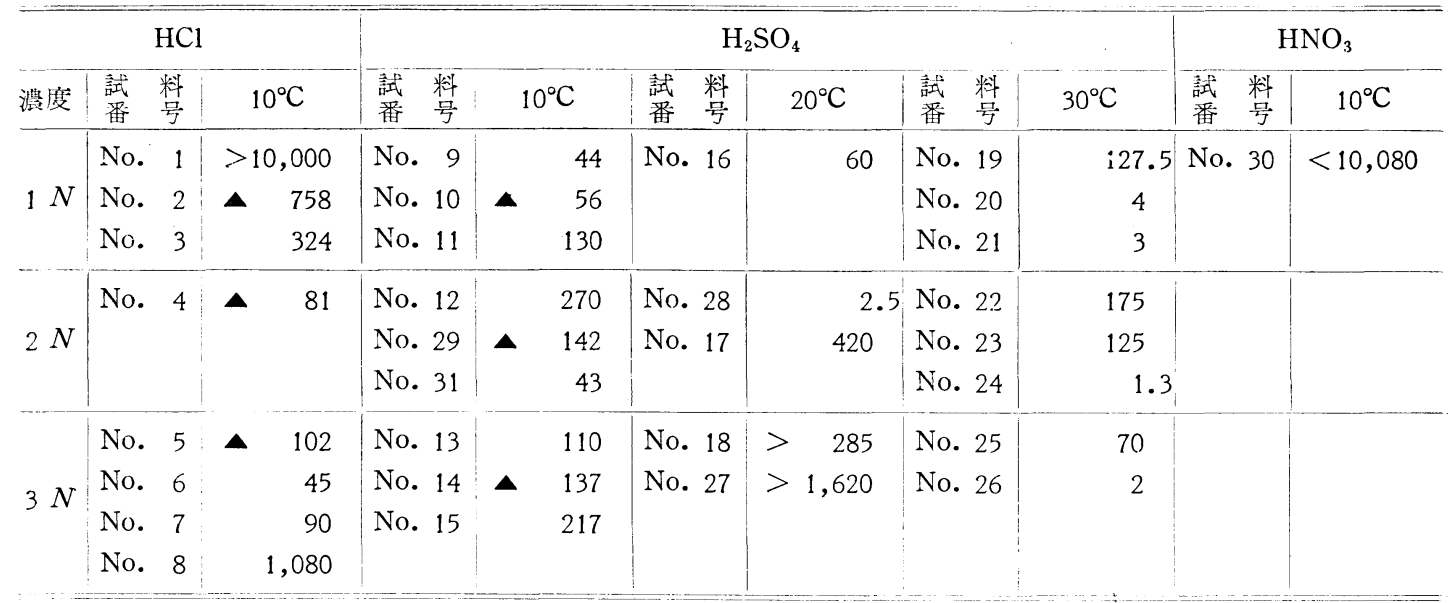

ム印は片面に黒皮を残した試料，他は両面切削したもの，>印はこの時間で実験を打切つたもの 


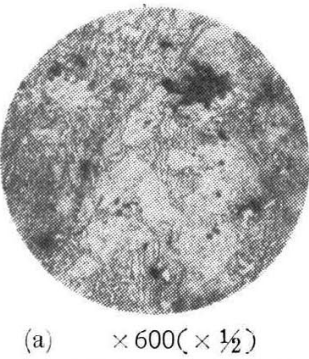

写真1 $\alpha$ の最大侹をボした絾料の絗織

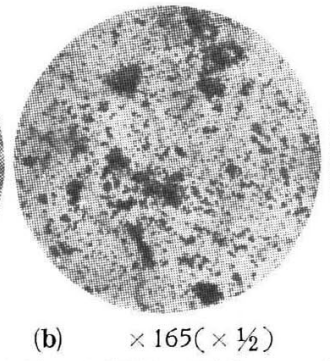

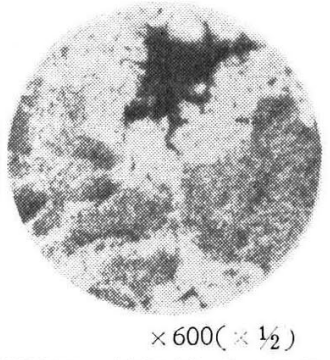

写真 2 試料 No.2 の絗織

\section{3-3 $\alpha$ 值と黒鉊粒との関係}

これらの試料を 0-4エメリ一紙 で研摩して, 7 倍の払大鏡（精光 器機製 Eye Gauge) で約 $45^{\circ}$ の 斜光線をあてて検左したところ, 径大の黑鉛粒のあるものは黑鉛を 失い空洞となっていることがわか った。これらが空洞であること 注，金属顕徽鏡を用いてまず研糜 闻にピントを合わせ，つぎに空洞 の底部にピントを令わせることによって確認できだ。 径大の照鉛粒でも, 星形に阳方に足を放出している上 5な黑鉛䊀は，黑鉛で満たされていることがわかった。 これに反し多くの球状（不整形ではあるが）のものは黑 雓を失い空洞になっていることを認めた。これは研摩中

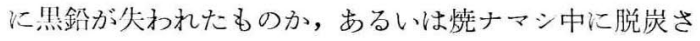
れたものか明らかでない。

これら空洞となった黒鉛の分布状態をスンプ法にてセ ルロイドの薄板に写しとりこれを印画紙上に14倍（x 3/4) に执大したものを写真 3に示した。

武料の断面を0-4 エメリ一紙で研摩し，破摩面汇现わ れた架洞の数を直径別に読みとり，空洞の総面積を求め る。これは前記のように研摩面に斜光線をむて, 約 7 倍 の桩大鏡を川いて容易に求めることがでさた。この空洞 の総面積とこれれらが存在した試料断面の面積との百分 脐を有孔度（P\%）とした。このPの值とハの值との関 係を求めた。

酸処理後の試料を一定の場所において切断し, この断 洎を研摩してPを求めた。

$\alpha$ の值の大きい試料は $\mathrm{P}$ の值が小さく, $\mathrm{P}$ は $\alpha$ の值に 机过するきわめて有意な值であることがわかった。 特に 3--2-3 の一群の試料については $\alpha \mathrm{P}^{2}=\mathrm{K}, \mathrm{K}=$ 約 2500 のような関倸があった。また3-2-4の一群の

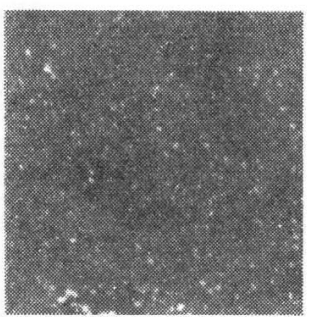

(a) 層状パーライトを残し た組織

㫼料 No. 1

$1 \mathrm{~N} \mathrm{HCl} 10^{\circ} \mathrm{C}$ にて $\alpha=10080 \mathrm{~min}$

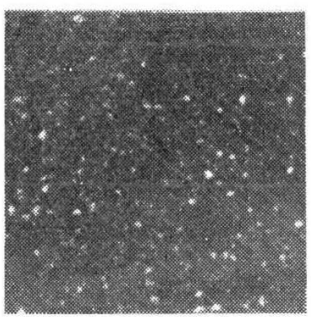

(b) フェライト紬織

試料 No. 22 $2 \mathrm{~N} \mathrm{H}_{2} \mathrm{SO}_{4} 30^{\circ} \mathrm{C}$ 亿て $\alpha=175 \mathrm{~min}$

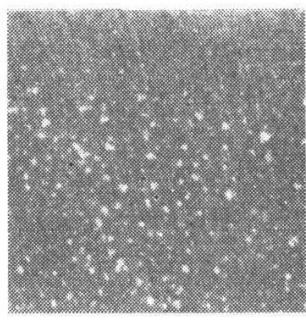

(c)フェライト組織

故料 No. 25 $3 \mathrm{~N} \mathrm{H}_{2} \mathrm{SO}_{4} 30^{\circ} \mathrm{C}$ $\alpha=70 \mathrm{~min}$

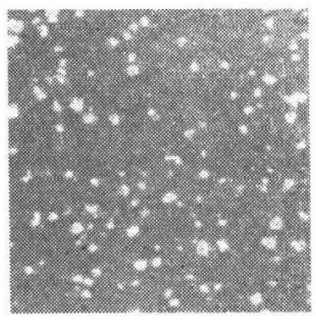

(d)フェライト組織

試料 No. 28

$2 \mathrm{~N} \mathrm{H}_{2} \mathrm{SO}_{4} 20^{\circ} \mathrm{C}$ $\alpha=2.5 \mathrm{~min}$

写真3 空润となった黒鉙の分布状態をスンプ法にて14㫦（×3/4）に拡大したもの 
試料，寸なわち径大の黑鉛粒が析计しているものの地に おける結晶粒間の境界線は非常比料大であった。このよ うな試料に预いてはP の佔も大きいが $\alpha$ の值は異状に小 さくなっている。また照鉛粘が一線七に連続して析出し

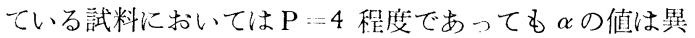
状に小さくなっている。

\section{3-4＼cjkstart硫酸処理における透過ガスの放出状態}

試料を硫酸処理した劫令, ガスが透過放出される京で の時間 $(\alpha \mathrm{min})$ を測定した後, 長時問ガス透過放出（以 下単に放出とい5）の状態を調べた。このグラフにおい て $x$ 軸に時問 $(\mathrm{hr}), y$ 軸にマノメ一タ一水銀柱の指差 (mmHg) をとり，3-2-1〜4 の 4 種類の組織につい て関係曲線を求めたところそれぞれ第 2 図に示すような 特徴ある曲線となった。

3-4一1 層状パーライトを残している組織

試料 $\mathrm{No}^{2} 273 \mathrm{~N} \mathrm{H}_{2} \mathrm{SO}_{4} 30^{\circ} \mathrm{C}$ に処理し， $27 \mathrm{hr}$ にいた ってもガス透過しなかった。試料 No. 27 の hr-mm $\mathrm{Hg}$ 関係曲線はすべて $x$ 軸上:にある。

\section{3-4-2 Bull's eye 組織}

ガス放出までの時間 $(\alpha \min )$ を $x$ 軸上にとる（以下 この部分を $\alpha$ とよら゙)。つぎにガスが放出し始めてから の $\mathrm{hr}-\mathrm{mmHg}$ の関係線を $\beta$ とする。ガス放出量 $(\mathrm{mm}$ $\mathrm{Hg})$ は hr に比例し $\beta$ は㨁線となる。及の勾配

$$
\left(\frac{\mathrm{mmHg}}{\mathrm{hr}}=\tan \theta\right) \text { を検鄙したところ } \tan \theta \text { の }
$$

值は試料 No.17 において 0.07 であった。 $\alpha=420 \mathrm{~min} て ゙$ わった。

3-4-3 フェライト地の黑鉊粒が粗大でない組織

$\mathrm{hr}-\mathrm{mmHg}$ 関係線は上記の3-4-2の場合と類似であ った。しかし $\beta$ の勾配 $(\tan \theta)$ の值は 1.4 4.1 であっ 态。

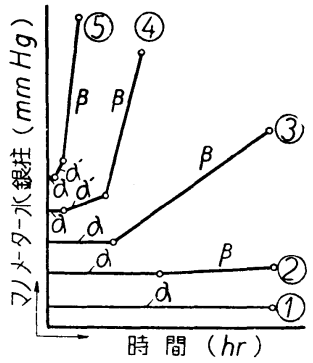

(1)㥜状パーライトを残し 埋鉊粒小

(2) Bull's eye 黑銛粒小

(3)フエライト地黑銛粒中

(4)フエライト地黑鉛粒大

(5) "

第2図各組織によって異な る水素ガス透過の模型! 的曲線（硫酸の莂合）
またガス放仙までの時間 $\alpha \min$ と $\tan \theta$ の積 $\alpha \tan \theta$ $=\mathrm{K}(\mathrm{K}$ の值は約 268）の上5な関倸が成立した。

これらの閔係を第3図に示した。

3-4-4フェライト地で黑鉛粒粗大な組織

ガス放出までの時間 $\alpha \min を x$ 軸上にとり，その後 のガス放出曲線は 2 本の勾配の異なった直線となった。 初期の直線を $\alpha^{\prime}$ とし, 後期の直線を $\beta$ とする。 $\beta$ の勾 配 $\tan \theta$ の倪は80〜150であった。

直線 $\alpha^{\prime}$ の存在することはこの組織の試料にのみ現わ れた特䔬な現象であった。このことはこれらの試料の地 の結晶粒間境界線が粗大となっているために, 試料中に 水素ガスが飽和する前に Boundary を通して一部の水 素がガス状となって放出されることを意味しているすの と思われる。したがって，水素が飽和するまでの時間 $(\min )$ は $\beta$ を延長して $x$ 軸と交わる点を求めて真の $\alpha$ の值とするのが妥当と思われる。

\section{3-5 塩酸処理の場合ガス透過放出状態}

㷪酸処理によって得た試料の数が少ないため, 結論を 出すことは组難であるが，得られた実験結果はすべて同 様な傾向を示したので一応の考察を試みた。これらの関 係を第 4 図に示した。

\section{3-5-1 層状パーライトを残す組織}

$\mathrm{hr}-\mathrm{mmHg}$ 関係線は硫酸の場合と同様であるが，試 料 No.1によって得られた $\alpha=10080$ のような大きな值 から考劣ると，このような組織は塩酸処理において水素 ガス浸透に対して非常に大きな抵抗があることがわかっ た。

\section{3-5-2 Bull's eye 組織}

ガス放出曲線は $\alpha, \alpha^{\prime}$ および $\beta$ の 3 直線から成立っ ている。硫酸処理の場合と非常に異なっ ている点はつぎの 2 点である。ガス放出 曲線の一部 $\alpha^{\prime}$ は硫酸の場合に扮いては

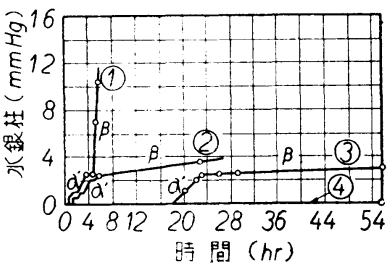

(1) 粗大黑鋁ト地(d) $114 . \quad 2.5 \quad 2 \mathrm{~N} \mathrm{H}_{2} \mathrm{SO}_{4} 20^{\circ} \mathrm{C}$ (2)フエライト地(c) $\quad 4.1 \quad 70.0 \quad 3 \mathrm{~N} \mathrm{H}_{2} \mathrm{SO}_{4} 30^{\circ} \mathrm{C}$ (3) " " $2.0 \quad 127.5 \quad 1 \mathrm{NH}_{2} \mathrm{SO}_{4} 30^{\circ} \mathrm{C}$ (4) " " $\quad 1.4 \quad 175.0 \quad 2 \mathrm{NH}_{2} \mathrm{SO}_{4} 30^{\circ} \mathrm{C}$ (5)Bull's eye (b) $\quad 0.07 \quad 420.0 \quad 2 \mathrm{NH}_{2} \mathrm{SO}_{4} 20^{\circ} \mathrm{C}$ (6)パーライト(a) >1620.0 $3 \mathrm{NH}_{2} \mathrm{OO}_{4} 20^{\circ} \mathrm{C}$

第3図硫酸贬理における水素ガス 透過状態

\begin{tabular}{|c|c|c|}
\hline 蟣 & $\alpha \min$ & 酸 \\
\hline (1)フエライト(d) & 45 & $3 N \mathrm{HCl} 10^{\circ} \mathrm{C}$ \\
\hline$\prime \quad(c)$ & 90 & " \\
\hline (3) Bull's eye (b) & 1080 & " \\
\hline (4)パーライト(a) & $>10080$ & $1 N \mathrm{HCl} 10^{\circ} \mathrm{C}$ \\
\hline
\end{tabular}

第 4 図填酸処理の水素ガス 透過状態 
直線 $\alpha$ に包含されうる性質のものであるが，嫶酸の場 合においては $\alpha^{\prime}$ は直線 $\beta$ の一部を成するのと考えられ る。 $\beta$ の勾配 $(\tan \theta)$ の值は $\alpha^{\prime}$ の勾配 $(\tan \theta)$ の值に 比較して非常に小さい。これらのことは㦈酸で閔㭙間処 理する場合， $\mathrm{Cl}^{\prime}$ の酸化作朋によって発生:期水素の浸透 が妨げられることに起因するものと思われる。

3-5-3フェライト地の黒鉛粒が粗大でない組織

ガス放出曲線は上記 3-5-2 の場合と全く類似のもの であった。 $\alpha$ は短かく， $\beta$ はやや勾配が大きくなってい るが， $\alpha^{\prime}$ は勾配も長サもほとんど同一であった。

\section{3-5-4 フェライト地で黒鉛粒粗大な組織}

この場合のガス放出曲線を前記3-5-2および3-5-3 と比較して非常に異なった状態を示している。この放出 曲線はむしろ硫酸の場合の 3-4-4 と類似している。こ のことは試料の地における結晶粒間境界線が粗大である ため $\mathrm{Cl}^{\prime}$ の酸化作用の効果は消失し, 硫酸の場合と同様 な傾向を示したものと思われる。したがってこのような 組織のものにおいては $\alpha^{\prime}$ は $\alpha$ に包含されるものと思わ れる。すなわ酸処理が開始されて試料中に水素がスが 飽和される前に Boundary を通してガスの放出が始ま るものと思われる。

\section{3-6 酸の濃度および温度の影響}

黒心可鍛鋳鉄に稆いては白銑時に同-・化学組成で同様 な組織を持っている一群の試料でも, その後の長時間に わたる復雑な熱処理中に加熱冷却速度の相舅, 温度分布 その他気圈などの状態が一定になり難く, 熱処理後の各 試料の地の組織および黑鉊粒の析出状態が非常に異なっ てくる。

したがって酸の濃度および温度の影響は同一の試料に ついて実験を行ならべきであることがわかった。しかし 同一試料について酸処理を繰り返すことにより素材中に 残る水素ガスのために水素ガスの透過放出するまでの嚇 間 $\alpha \min$ は求め難くなる。しかしフェライト地の陚料に ついて硫酸処理を行なら場合には3-4-3に述べたよう に $\alpha \tan \theta=268$ の関係がある故に硫酸の濃度または温 度を変えて長時間ガスを透過せしめ $\beta$ の勾配 $\tan \theta$ の 変化を求めれば $\alpha$ の近似值を知ることができるものと 考えられる。またフェライト地に粗大な黒鉛粒の析出し たものに沶いては $\beta$ と $x$ 軸の交点を求めこれより試料 中に水素ガスが飽和されるまでの時間 $\alpha$ を求めること ができるものと考えられる。

\section{3-6-1 酸の濃度の影響}

上記の方法によって同一試料について酸の濃度变化の 影響を実験した。用いた試料はフェライト地に粗大な黑 鉛粒を析出する（Pは約 $8 \%$ ）ものであった。温度 $30^{\circ} \mathrm{C}$ に拈いて硫酸の濃度を $1 N$, $2 N$ および $2.3 N$ について $\beta$ の勾配を求めた。その結果 $\tan \theta$ は $80.25,180.6$ お
よび 248.4のよ5に変化した。すなおち $\tan \theta=80 N+$ $0.0027 l^{5.65 N}$ のように变化した。

これらの結果を第 5 図に示した。

またフェライト地の $\mathrm{P}=4 \%$ 程度の相似の組織を持つ, 2 枚の試料 No. 19 および No. 23 について検討したと ころ, 第 1 表のように, 硫酸 $30^{\circ} \mathrm{C}$ に抮いて $1 N$ および $2 N$ の相異によって $\alpha$ の值は 127.5 および 125 のよう にほとんど変化が認められなかった。

これらの結果から考察すれば, 粗大な黒鉛粒と粗大な Boundary を持つ素地に氺いては, 酸の濃度に非常な影. 響を受け，Boundaryは長時間のガス透過によってます ますガスを通しやすい状態になるものと考えられる。

$3-6-2$ 温度の影響

フェライト地で黑鉊粒の析出は $\mathrm{P}=4 \sim 4.5 \%$ の 3 枚 の試料を用いて， $2 N$ 硫酸について温度 $20^{\circ} \mathrm{C}$ および $30^{\circ} \mathrm{C}$ にお沙る $\tan \theta$ の变化を求めた。

この実験においては各試料ともガス透過の過程におい て温度を变承して曲線の勾配 $\tan \theta$ の変化を検討したも のである。その結果は次のと抢りであった。

\begin{tabular}{c|c|c|c}
\hline & $20^{\circ} \mathrm{C}$ の $\tan \theta$ & $30^{\circ} \mathrm{C}$ の $\tan \theta$ & 比 \\
\hline 1. & 1.75 & 2.34 & 1.4 \\
2. & 1.0 & 1.4 & 1.43 \\
3. & 1.4 & 2.0 & 1.33 \\
\hline
\end{tabular}

またフェライト地の琴鉊粒粗大なものにおいては， 温度による影響はほとんど見られなかった。このことは Boundary の粗大なものにおいては水素ガスは非常に透 過しやすく普通の素材が非常に高温にさらされたときと

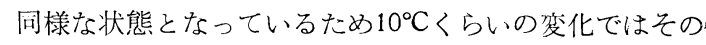
影響が現われなかったものと思われる。

\section{4. 結論}

白銑時の化学組成が C $2.81 \%$, Si $0.95 \%$, Mn 0.38 \%, S 0.08\%の第 2 段黑鉛化を施したフェライト型黑心 可鍛鋳鉄 $3 \mathrm{~mm}$ 厚の一 群の試料について $\mathrm{HCl}$ ， $\mathrm{H}_{2} \mathrm{SO}_{4}$ を用い温度 10 $30^{\circ} \mathrm{C}$, 濃度 $1 \sim 3 N$ Kて 酸処理し, 主として酸洗 時澄生する発生期水素 によって飽和されるまで の時間 ( $\alpha \mathrm{min})$ につい て测定した。その結果つ ぎの諸点を解明すること ができた。

（1）白銑時同一組成の

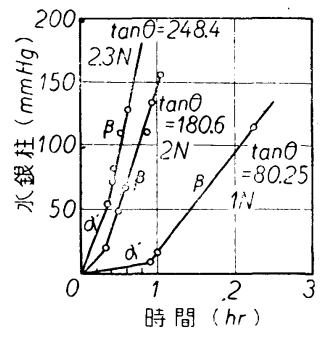

第5図同一試料を用いた 硫酸の濃度の影響 温度 $30^{\circ} \mathrm{C}$ フェライ 卜地黒鉛粗大 
一群の試料でも, その後の長時間にわたる熱処理中に加 熱泠却速度, 気圈などの条件が一定に保ち難く, 熱処理 後の素地の組織, 析出黑鉛などの状態が不同となり一定 した一群の試料が得られなかった。

(2) これらの試料のうら層状パーライト組織を残し, 小径の黑鉛粒が析出した素材は酸洗によって生ずる発生 期水素の払散漫透に対して非常な抵抗を持ら， $\alpha=1620$ 〜10080 min 以上であった。

(3) Bull's eye 組織で析出した黒鉛粒が小径の素材 においては， $a=420$ 1080 min であった。

(4) フェライト地で析出した黒鉛精が小径の素材にお

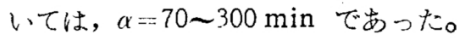

(5) フェライト地で黒鉛粒粗大なものに拈いては, 素

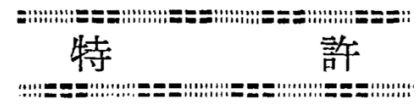

\section{光沢銅メッキ浴}

米国特儌 2,842,488

W.Strauss, A.Kirstahler, W.D.Willmund

出願者 Deutsche Hydriewerke G.m.b.H.

酸性銅メッキ浴より光沢銅を電着させる方法として， 㴼液に硬水，工業用銅垭括よでスルホン酸系光沢剂を使 う，この光沢戍はつぎ構造を有する carboxyl 基を持 たない化合物 $0.01 〜 20 \mathrm{~g} / l$ を扣克ることにより epichlorohydrin と共に生ずる第 4 級アンモニウム塩と銅 塩によって浴打に念まれる。

前記化合物の構造任

$$
\mathrm{G}-\mathrm{R}-\mathrm{N}<\frac{\mathrm{R}_{1}}{\mathrm{R}_{2}}
$$

ここに $\mathrm{R}$ は低 alkylene, mono hydroxy lower alkylene, および phenyl のいずれかであり。Gは水素, cyano, thiocyano および nitroのうちのいずれか, ま た $\mathrm{R}_{1}$ 招よび $\mathrm{R}_{2}$ は lower alkyl, mono hydroxy lower alkyl, phenyl, cyclohexyl おょび morpholino たた は piperidinoの中の窒素原子を含えでいる heterocyclic 基の5ちのいずれかである。また硬水や工業用 銅塩飞含末れている不純物はこのスルホン酸系光沢剂の 光沢作用に害を与光ることを防ぐ。

(

\section{銅および真銍の光沢剂}

\section{米国特部 2,838,448 1958年6月10日}

\section{D.R.France}

アルカリ性シアン化メッキ落より光沢，延性ある銅乱 よで真チュりを析出さやるための光沢剤としてつぎの割 合のものを加党る。光沢剂 1 gallonを作るには亚と酸ナ トリウム $2 \mathrm{oz}$, 硝酸ナトリウム $10 \sim 20 \mathrm{cz}$, 亜鉛ナトリ ウ $\triangle 10 \mathrm{oz}$, methyl alcohol 160z, forma!dehyde $160 z$, 界面活性剂 $32 \mathrm{oz}$, tetrathylrhodamine $1 \sim 5 \mathrm{~g}$ に水を加え 1 gallon とする。

\section{物体の表面に酸化クロムのフィルムを 形成する方法}

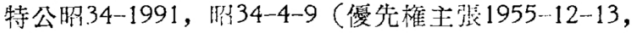
アメリカ)リッベー・オーウェンス・フォード・ダ ラス・コムパニー
地の結晶䊒閒境界線 (Boundary) \&また粗であるた め, 水素ガスの透過はいちじるしく速やかで, $\alpha=1 〜$ $45 \mathrm{~min}$ であった。また酸の濃度にいちじるしく影響を ら郆た。

（6）一般に㴼酸は硫酸より影響が少ない。

終りにのぞみ武料作成に協力された旭可鍛 K Kならび に実験遂行に協力された本学部松村孝, 河田米栄の両君 に感謝する。本研究の研究費の一部は文部省科学研究費 の補助によるものである。

（本報は昭和33年11月21日, 本協会・日本化学会共催 研究発表大公にて発表のもの)

(1959.2. 10 受理)

\section{文献}

(1) C.A.Edwards, J. Iron \& Steel Inst, 110, 9(1924)

物体の表面を $425^{\circ} \mathrm{C}$ 以上の温度まで加熱し, 前記加熱 表面に酸化クロム化合物の溶液を噴藩することよりなる 物体の表面に酸化クロムのフィルムを形成する方法。

(付㖖13)

(長坂)

\section{鉄鋼 の珐瑯被覆方法}

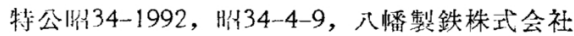

鉄銅の表面に電领画鉛メッキを施した後，リン酸西鉛 を主成分とする゙ン酸塩支膜を付着せしめたものにホウ

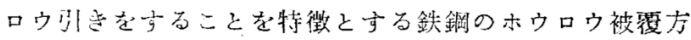
法。

(長坂)

\section{金属のような加熱可能な素材にポリエ チレンを層設する方法}

特公脽34-2433, 明34-4-14, 日本容器工業栋式会社 金属のような加熱叮能な素材を $200^{\circ} \mathrm{C}$ 程度飞加熱して その表面にホリエチレン粉末を溶射器を以って吹付け， その溶䤃状態に㧍いて固化状態のままのポリエチレン膜 または板を卟付け，しかる後冷却国化させることを特徽 とする金属のような加熱叮能な素枋氏ポリエチレンを層 設する方法。

(長坂)

\section{物体形成用または被覆形成用配合物}

特公肪34-2563, 明34-4-17（優先権主張1956-12-14 アメリカ)，ュニオン・カーパイト・コーポレーシ ヨン)

モリブデン，タングステン，タンタル，二オブまたは バナジウムの10〜 40原子\%と，ヶイ㮃の20〜65原子\%と クロム,チタンまたはジルコニウムの 2〜16原子\%とホ ウ素の2〜25原子％とアルミニウムの3〜30原子\%とから 成る。高温で高度の椋酸化性と高度の強サとをるつ物体 形成用配合物または高温で自琼性之高度の酎酸化性々を 母つ被覆形成用配合物。(付乱 7 )

(長坂)

\section{放 電 焼 入 装 置}

特公昭34-606, 昭34-2-12,

株式会社日本故電加工研究所

時間設定機構により制御される電磁石をスピンドルの 先端に配置して被焼入物を保持し，該スピンドルの移動 により動作するりミットスイッチによって電動機および リアクトル制御巻線の雪流を切換え，被焼入物飞送りを 与えると其比炶入電流を制御するようにした放電焼入装 紫.

( $\mathrm{F}$ 田) 